Article

\title{
Effects of cerium on the selective catalytic reduction activity and structural properties of manganese oxides supported on multi-walled carbon nanotubes catalysts
}

\author{
LI li a, WANG Lishan b,c, PAN Siwei a , WEI Zhengle a,b, HUANG Bichun b,d,* \\ a Electric Power Research Institute of Guangdong Power Grid Corporation, Guangzhou 510080, Guangdong, China \\ ${ }^{\mathrm{b}}$ College of Environmental Science and Engineering, South China University of Technology, Guangzhou 510006, Guangdong, China \\ cAtmospheric Research Center, Guangzhou HKUST Fok Ying Tung Graduate School, Guangzhou 511458, Guangdong, China \\ ${ }^{\mathrm{d}}$ Guangdong Provincial Key Laboratory of Atmospheric Environment and Pollution Control, Guangzhou 510006, Guangdong, China
}

\section{A R T I C L E I N F O}

\section{Article history:}

Received 5 November 2012

Accepted 21 December 2012

Published 20 June 2013

Keywords:

Selective catalytic reduction

Nitrogen oxide

Cerium

Manganese

Multi-walled carbon nanotube

\begin{abstract}
A B S T R A C T
A series of manganese and cerium oxides supported on multi-walled carbon nanotubes (MWCNTs) catalysts for low-temperature $\mathrm{NH}_{3}$ selective catalytic reduction (SCR) of $\mathrm{NO}_{x}$ were prepared by the pore volume impregnation method. The SCR activity of Mn-Ce/MWCNTs catalysts was compared with that of Mn/MWCNTs catalyst. The effects of Ce were characterized by transmission electron microscopy, $\mathrm{N}_{2}$ adsorption-desorption, $\mathrm{H}_{2}$ temperature-programmed reduction, $\mathrm{X}$-ray photoelectron spectroscopy and X-ray powder diffraction. The results show that the addition of cerium oxides could improve the SCR activity of Mn/MWCNTs catalysts. Mn-Ce/MWCNTs catalyst with a Ce/Mn ratio of 0.6 was found to have the highest activity. The addition of cerium oxides enhanced the dispersion of metal oxides on the MWCNTs. It could also increase the specific surface area and total pore volume, and decrease the average pore size of the catalysts. Ce would improve the concentration of oxygen and the valence of manganese. Furthermore, from the XRD results, it was obvious that the crystalline $\mathrm{MnO}_{x}$ disappeared because of the introduction of Ce to the catalyst. $\mathrm{MnO}_{x}$ mainly existed in an amorphous state or microcrystal structure in the Mn-Ce/MWCNTs catalysts. $\mathrm{CeO}_{2}$ was found to be the main phase for $\mathrm{CeO}_{x}$.
\end{abstract}

(C) 2013, Dalian Institute of Chemical Physics, Chinese Academy of Sciences. Published by Elsevier B.V. All rights reserved.

\section{Introduction}

Selective catalytic reduction (SCR) of $\mathrm{NO}_{x}$ with $\mathrm{NH}_{3}$ is one of the most effective flue gas cleaning technologies for stationary sources. The catalyst is the most important part of the SCR technology, and it determines the efficiency of the SCR system. However, commercial catalysts $\left(\mathrm{V}_{2} \mathrm{O}_{5}-\mathrm{WO}_{3}\left(\mathrm{MoO}_{3}\right) / \mathrm{TiO}_{2}\right)$ for these processes are active within a narrow temperature window of $300-400{ }^{\circ} \mathrm{C}$, and they will be deactivated by high concentrations of $\mathrm{SO}_{2}$ or dust [1,2]. Therefore, developing low-temperature SCR processes and catalysts, which can be installed after the desulfurizer and particulate removal device (below $200^{\circ} \mathrm{C}$ ), is of significant importance to prevent catalysts from being poisoned.

In the last decade, much of the literature focused on developing efficient SCR catalysts. A majority of the papers looked at active components and supports for low-temperature $\mathrm{NH}_{3} \mathrm{SCR}$ [3]. The $\mathrm{Fe}_{0.9} \mathrm{Mn}_{0.1} \mathrm{TiO}_{x}$ catalyst [4] has been reported to have high low-temperature SCR activity because of its high specific surface area, proper structure, high oxidizability, and high

\footnotetext{
*Corresponding author. Tel: +86-20-39380516; Fax: +86-20-39380518; E-mail: cebhuang@scut.edu.cn This work was supported by the National Natural Science Foundation of China (20977034). 
transfer capability of lattice oxygen. This catalyst allows for $\mathrm{NO}_{x}$ conversion of higher than $90 \%$ at reaction temperature of 200 ${ }^{\circ} \mathrm{C}$. Zamudio et al. [2] prepared the $\mathrm{Mn}_{0.95} \mathrm{Ca}_{0.05} \mathrm{Cr}_{2} \mathrm{O}_{4}$ catalyst via gel combustion synthesis, and the catalyst showed that the highest NO conversion was at a reaction temperature of $125^{\circ} \mathrm{C}$. Yao et al. [5] found that the SCR activity of the $\gamma-\mathrm{Fe}_{2} \mathrm{O}_{3}$ catalyst was higher than $90 \%$ at $250{ }^{\circ} \mathrm{C}$, which was attributed to the magnetism of $\gamma-\mathrm{Fe}_{2} \mathrm{O}_{3}$. Shen et al. [6] prepared a series of Ce-doped $\mathrm{Mn} / \mathrm{TiO}_{2}$-pillared clay catalysts and evaluated the effect of Ce on their performance in SCR reactions with $\mathrm{H}_{2} \mathrm{O}$ and $\mathrm{SO}_{2}$. The results show that Ce could improve SCR activity and catalyst resistance to $\mathrm{SO}_{2}$.

Many transition metals and their oxides can be used as active components for the SCR catalysts, such as $\mathrm{Mn}, \mathrm{Ce}, \mathrm{Fe}, \mathrm{Pt}$, and $\mathrm{Cr} . \mathrm{Mn}$ and $\mathrm{Ce}$ are among the most active transition metals because of their unique characteristics [2,5-8]. Manganese oxides exhibit strong redox abilities as there are many unstable lattice oxygen atoms on their surfaces [1,9-12]. Kang et al. [13] reported that the unloaded manganese oxide catalysts prepared by precipitation methods gave higher than $90 \% \mathrm{NO}_{x}$ conversion at reaction temperature of $100{ }^{\circ} \mathrm{C}$. It has been reported that $\mathrm{CeO}_{2}$ presents excellent oxygen storage capacity because it can release and store oxygen according to the transformation between $\mathrm{Ce}^{4+}$ and $\mathrm{Ce}^{3+}$ [14]. Huang et al. [15] and $\mathrm{Wu}$ et al. [16] mentioned that the addition of Ce to SCR catalysts improved low-temperature SCR activity.

$\mathrm{TiO}_{2}, \mathrm{Al}_{2} \mathrm{O}_{3}$, zeolite, and carbon materials have been widely studied for use as SCR catalyst supports [9,17-19]. Carbon materials have been reported to be excellent catalyst supports because of their high specific surface area, particular pore structure and high adsorptive properties. Carbon nanotubes (CNTs), as a special orderly carbon materials, have been widely reported as successful catalyst supports based on their unique electronic properties and structure, such as strong mechanical strength, good thermal stability, quantum confinement effect and good conductivity [24-26].

Based on previous investigation of Mn/MWCNTs catalysts, a series of Mn-Ce/MWCNTs catalysts were prepared for this study by the pore volume impregnation method. The effects of Ce on the catalyst structure and SCR activity were studied using transmission electron microscopy (TEM), nitrogen adsorption, $\mathrm{X}$-ray photoelectron spectroscopy (XPS), X-ray powder diffraction (XRD), $\mathrm{H}_{2}$ temperature-programmed reduction ( $\left.\mathrm{H}_{2}-\mathrm{TPR}\right)$, and SCR activity tests.

\section{Experimental}

\subsection{Catalyst preparation}

MWCNTs with outer diameters of 60-100 nm were purchased from Shenzhen Nanotech Port Co. Ltd and were purified with $3 \mathrm{~mol} / \mathrm{L} \mathrm{HNO}_{3}$ solution for $4 \mathrm{~h}$ at $100{ }^{\circ} \mathrm{C}$, then washed with distilled water and dried in a convection oven at $80^{\circ} \mathrm{C}$ overnight. MWCNTs were then pretreated in oxygen dielectric barrier discharge (DBD) plasma at a discharge power of $15 \mathrm{~W}$ for $40 \mathrm{~min}$. The purpose of the DBD plasma process is to introduce oxygen containing functional groups to the surfaces of the
MWCNTs, which improves the dispersion stability of MWCNTs in water. As a result, the introduction of active components to MWCNTs can be performed in water [27].

A series of Mn-Ce/MWCNTs catalysts were prepared by the pore volume impregnation method. Mixed solutions of manganese acetate and cerous nitrate were made with certain molar ratios of $\mathrm{Ce} / \mathrm{Mn}$ and a constant $\mathrm{Mn}$ loading of $10 \mathrm{wt} \%$. The mixed solution was then added to the beaker containing MWCNTs. This mixture was sonicated for $1 \mathrm{~h}$ for better dispersion of MWCNTs in the solution. After impregnation, the samples were dried in air at $100{ }^{\circ} \mathrm{C}$ for $12 \mathrm{~h}$, then calcined in a tubular furnace in atmospheric conditions of air at the desired temperatures for $2 \mathrm{~h}$. The catalysts were denoted as Mn-Ce $(x) /$ MWCNTs, where $x$ represents the molar ratio of Ce to $\mathrm{Mn}$. When the manganese acetate or cerous nitrate was not added, the catalyst was denoted as Ce/MWCNTs or Mn/MWCNTs.

\subsection{Catalyst activity test}

The steady state SCR reaction was performed in a quartz tube (inner diameter was $12 \mathrm{~mm}$ ) fixed-bed continuous flow reactor using $180 \mathrm{mg}$ catalyst of 40-60 mesh. The typical reactant gas composition was $\mathrm{NH}_{3}(0.1 \%)$, $\mathrm{NO}(0.1 \%), \mathrm{O}_{2}(5 \%)$, and the balance of Ar. Mass flow controllers controlled the gas flow rates. The gas hourly space velocity (GHSV) was fixed at 40000 $\mathrm{h}^{-1}$. The inlet and outlet concentrations of $\mathrm{NO}_{x}$ were monitored by a $\mathrm{NO}_{x}$ analyzer (42i-HL, Thermo Ins.).

The $\mathrm{NO}_{x}$ removal efficiency was determined by the following equation: $X\left(\mathrm{NO}_{x}\right)=\left(C_{\mathrm{NO} x}^{\text {in }}-C_{\mathrm{NOx}}^{\text {out }}\right) / C_{\mathrm{NO} x}^{\text {in }} \times 100 \%$. Where $C_{\mathrm{NOx}}^{\text {in }}$ and $C_{\mathrm{NOx}}^{\text {out }}$ correspond to the inlet and outlet concentrations of $\mathrm{NO}_{x}$, respectively.

\subsection{Catalyst characterization}

The morphologies of Mn-Ce/MWCNTs catalysts were investigated by a JEOL JEM-2100HR transmission electron microscope at an accelerating voltage of $200 \mathrm{kV}$. The point resolution was $0.23 \mathrm{~nm}$, the enlargement factor was $50-1500000$, and the acceleration voltage was $100-200 \mathrm{kV}$. The specific surface area, pore volume and pore size of the samples were determined by nitrogen adsorption on an ASAP 2020 M (Micromeritics, USA). Before testing, $0.1 \mathrm{~g}$ of the sample was pretreated for $1 \mathrm{~h}$ at 350 ${ }^{\circ} \mathrm{C}$ to remove any adsorbed gases. The measurement was performed at $-196{ }^{\circ} \mathrm{C}$ (liquid nitrogen temperature) using a static-volumetric method. $\mathrm{H}_{2}$-TPR experiments were performed with an Auto Chem II (Micromeritics, USA). The samples were pretreated in $\mathrm{Ar}$ at $350{ }^{\circ} \mathrm{C}$ for $1 \mathrm{~h}$. Samples were then treated from 60 to $700{ }^{\circ} \mathrm{C}$ at a heating rate of $10{ }^{\circ} \mathrm{C} / \mathrm{min}$ in $10 \% \mathrm{H}_{2} / \mathrm{Ar}$ (30 ml/min). The $\mathrm{H}_{2}$ consumption was determined by a TCD detector. XPS (Axis Ultra DLD, Kratos, UK) was used to analyze the chemical state and surface composition of samples. All spectra were acquired at a basic pressure of $25 \times 10^{-9}$ Torr with $\mathrm{Al} K_{\alpha}$ radiation $(h v=1486.6 \mathrm{eV})$ at $15 \mathrm{kV}$. The binding energy calibration was performed using the $\mathrm{C} 1 \mathrm{~s}$ peak in the background as the reference energy (284.6 eV). XRD measure- 
ments were taken on a D8 Advance Diffractometer (Bruker, Germany) with Ni-filtered $\mathrm{Cu} K_{\alpha}$ radiation ( $\lambda=0.15418 \mathrm{~nm}, 40$ $\mathrm{kV}, 40 \mathrm{~mA}$ ) in the $2 \theta$ range of $5^{\circ}-90^{\circ}$. The XRD phases were identified by comparison with reference data files from the Joint Committee on Power Diffraction Standards (JCPDS).

\section{Results and discussion}

\subsection{SCR activity of the catalysts}

Patterns of the catalytic activity of Mn-Ce/MWCNTs catalysts are presented in Fig. 1. The results show that the $\mathrm{NO}_{x}$ conversions for all samples were within $20 \%-40 \%$ at reaction temperatures below $120{ }^{\circ} \mathrm{C}$. With increased reaction temperature, obvious differences in $\mathrm{NO}_{x}$ convention appeared for all the samples, with most of the samples showing higher SCR activity. $\mathrm{NO}_{x}$ conversion reduced when the reaction temperature increased above $240{ }^{\circ} \mathrm{C}$. This was attributed to a competitive reaction with the SCR reaction. $\mathrm{NH}_{3}$ was oxidized by oxygen in high temperature conditions, which has also been observed for some other catalysts [28-30].

For the Mn/MWCNTs catalyst, NO conversion was below $60 \%$ when the reaction temperature was lower than $180{ }^{\circ} \mathrm{C}$. The NO conversion sharply increased to $97.9 \%$ when the reaction temperature increased to $210^{\circ} \mathrm{C}$. The conversion efficiency also remained above $90 \%$ at higher reaction temperatures. The active temperature window was large for this catalyst $\left(210-300{ }^{\circ} \mathrm{C}\right)$. In the case of Ce/MWCNTs catalyst, the $\mathrm{NO}_{x}$ conversion increased with an increase in the reaction temperature $\left(60-300{ }^{\circ} \mathrm{C}\right)$. However, the $\mathrm{NO}_{x}$ conversion efficiency was low, at $73.6 \%$ with reaction temperature of $300{ }^{\circ} \mathrm{C}$. Compared with the active temperature windows of the catalysts above, Mn-Ce/MWCNTs catalysts are active at lower temperatures. With an increased $\mathrm{Ce} / \mathrm{Mn}$ ratio from 0.2 to 1.8 , the active tem-

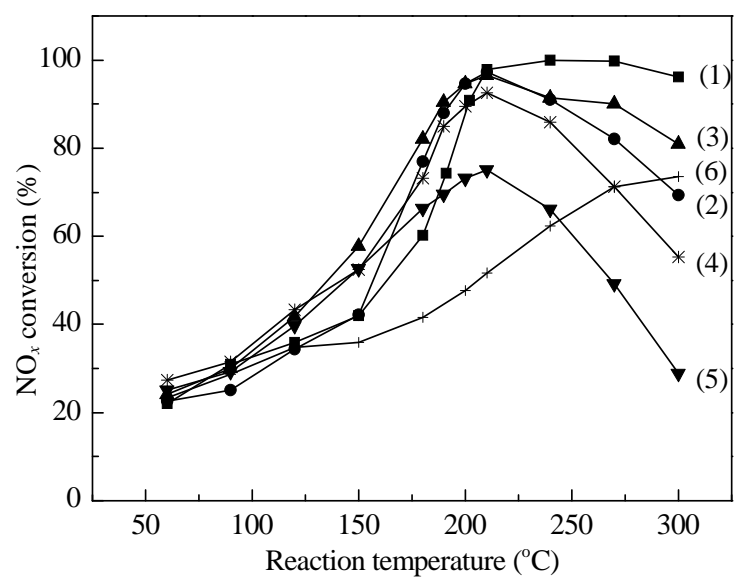

Fig. 1. SCR activity of various $\mathrm{Mn}-\mathrm{Ce}(x) / \mathrm{MWCNTs}$ catalysts. (1) Mn/MWCNTs; (2) Mn-Ce(0.2)/MWCNTs; (3) Mn-Ce(0.6)/MWCNTs; (4) Mn-Ce(1.2)/MWCNTs; (5) Mn-Ce(1.8)/MWCNTs; (6) Ce/MWCNTs.

perature window of the catalyst grew and then narrowed. With a $\mathrm{Ce} / \mathrm{Mn}$ ratio of 0.6 , the catalyst showed the highest catalytic activity and the largest active temperature window. Its $\mathrm{NO}_{x}$ conversion remained above $90 \%$ when the reaction temperature was within the range of $190-270{ }^{\circ} \mathrm{C}$.

To investigate the effects of Ce modification on the SCR activity of Mn/MWCNTs catalysts and the dispersion of Mn in MWCNTs, several catalysts listed below were selected to be further characterized, including Mn/MWCNTs, Ce/MWCNTs, Mn-Ce(0.6)/MWCNTs, and Mn-Ce(1.8)/MWCNTs catalysts.

\subsection{Characterization of the catalysts}

\subsubsection{TEM results}

The TEM images of the samples are shown in Fig. 2. From
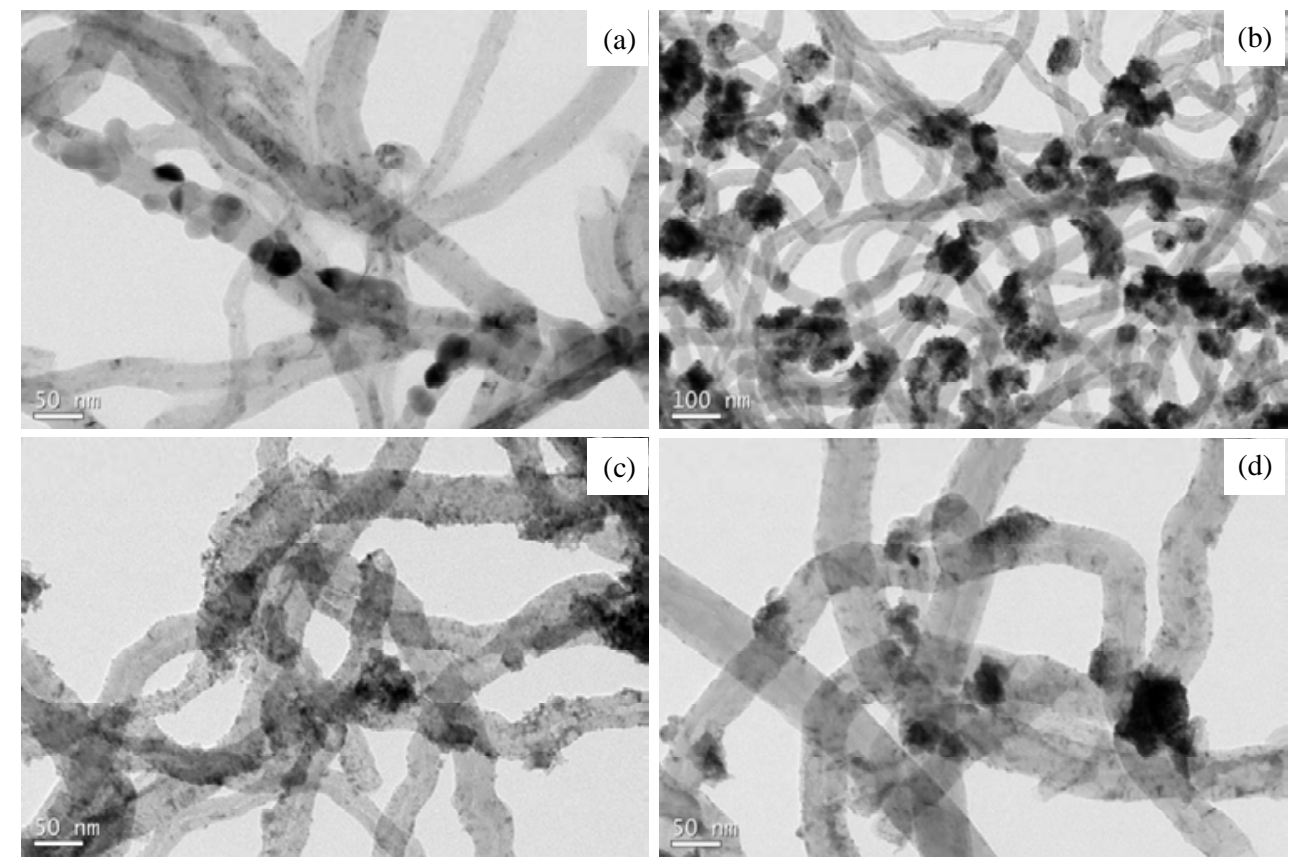

Fig. 2. TEM images of various catalysts. (a) Mn/MWCNTs; (b) Ce/MWCNTs; (c) Mn-Ce(0.6)/MWCNTs; (d) Mn-Ce(1.8)/MWCNTs. 
the image showing Mn/MWCNTs (Fig. 2(a)), it was found that $\mathrm{MnO}_{x}$ particles were uniformly dispersed on the surface of the MWCNTs with diameters between 10 and $40 \mathrm{~nm}$. In Fig. 2(b), $\mathrm{CeO}_{x}$ particles agglomerated on the surface of the nanotubes. The diameters of the particles were from 50 to $100 \mathrm{~nm}$. When both Ce and Mn were supported on MWCNTs (Figs. 2(c) and (d)), the dispersion of the metal oxide particles improved and the particle diameters were reduced to less than $10 \mathrm{~nm}$. Reaction gases easily make good contact with the active sites on the surface of the Mn-Ce/MWCNTs catalysts, enhancing the SCR activity. When the Ce/Mn ratio reached 1.8 (Fig. 2(d)), the metal oxide particles aggregated together and some active sites became hidden. This kind of metal oxide agglomeration is loosened rather than pyknotic.

\subsubsection{Nitrogen adsorption}

Detailed textural data of the catalysts are summarized in Table 1. It was shown that for most of the catalysts except for the Ce/MWCNTs catalyst, the specific surface area was enlarged while the total pore volume and average pore size decreased after supporting the metal oxides. For the Ce/MWCNTs catalyst, because of the agglomeration of $\mathrm{CeO}_{x}$ particles, the specific surface area and total pore volume were reduced while the average pore size increased after loading with $\mathrm{CeO}_{x}$ Comparing the four catalysts, it was observed that the addition of Ce increased the specific surface area and total pore volume while reducing the average pore size. After introducing Ce to the $\mathrm{Mn} /$ MWCNTs catalyst $(\mathrm{Ce} / \mathrm{Mn}=0.6)$, the average pore size decreased, but the specific surface area and the total pore volume increased by $24 \%$ and $18 \%$, respectively. It was believed that metal oxide particles dispersed well on the surface of MWCNTs in an amorphous state or microcrystal structure based on the interactions between $\mathrm{Ce}$ and $\mathrm{Mn}$ atoms. A large number of tiny tunnels were formed and the metal oxides exposed enough to improve the specific surface area (TEM and $\mathrm{XRD}$ results). As the value of the $\mathrm{Ce} / \mathrm{Mn}$ ratio continued increasing (1.8), the $A_{\mathrm{BET}}$ nearly doubled that of the Mn-Ce(0.6)/MWCNTs catalyst, and the total pore volume also continued to increase. The excess metal oxides aggregated together to form loosened particles after dispersing on the surface of the MWCNTs. However, the average pore volume is reduced sharply because of excess loading (Mn was $10 \mathrm{wt} \%$ and Ce was $45 \mathrm{wt} \%)$. The average pore size of the Mn-Ce(1.8)/MWCNTs catalyst was similar to that of the unloaded $\mathrm{MnO}_{x}-\mathrm{CeO}_{2}$ catalysts reported by Gong et al. [31] and Qi et al. [14], which had Ce/Mn ratios of 2.3 and 2.5, respectively. Considering the SCR activity, it is suggested that when the

Table 1

The surface area, pore volume, and average pore diameter of different catalysts.

\begin{tabular}{lccc}
\hline Sample & $A_{\mathrm{BET}} /\left(\mathrm{m}^{2} / \mathrm{g}\right)$ & $V_{\text {Total }} /\left(\mathrm{cm}^{3} / \mathrm{g}\right)$ & $\begin{array}{c}\text { Average pore } \\
\text { size }(\mathrm{nm})\end{array}$ \\
\hline MWCNTs & 35 & 0.138 & 15.9 \\
Mn/MWCNTs & 37 & 0.109 & 11.7 \\
Mn-Ce(0.6)/MWCNTs & 46 & 0.129 & 11.3 \\
Mn-Ce(1.8)/MWCNTs & 75 & 0.134 & 7.1 \\
Ce/MWCNTs & 26 & 0.111 & 16.8 \\
\hline
\end{tabular}

$\mathrm{Ce} / \mathrm{Mn}$ ratio is 0.6 , the large specific surface area and proper pore structure would improve the SCR activity. However, the specific surface area and SCR activity did not always correlate well with each other. When the value of $\mathrm{Ce} / \mathrm{Mn}$ was increased to 1.8 , the SCR activity decreased with the larger specific surface area.

Tang et al. [1] reported that the catalytic activity variations of the different Mn-based catalysts could be attributed to the specific surface areas, phases and structures. A larger specific surface area enhances the adsorption of the reagent, and provides more reaction space to the catalytic reaction. This then improves the $\mathrm{NO}_{x}$ conversion efficiency [10]. Reactant gases could easily adsorb on the surface of catalysts and promote the SCR reaction at low temperatures. In Table 1 , it was noted that the specific surface areas of different catalysts were quite different to others. However, their $\mathrm{NO}_{x}$ conversions were similar at reaction temperatures lower than $120^{\circ} \mathrm{C}$. It is indicated that the number of active sites on different Mn-Ce/MWCNTs catalysts varies significantly at low reaction temperatures. With an increased reaction temperature and desorption of reactant gases, the SCR activity did not reduce as expected, but increased. Therefore, it is believed that the effect of specific surface area on catalytic activity is weakened at higher temperatures. The phases and structures of the catalysts dominate the SCR activity.

\subsubsection{XRD results}

The XRD patterns of various catalysts are shown in Fig. 3. The pattern of Mn/MWCNTs catalyst exhibited the typical peaks corresponding to graphite $\left(2 \theta=26.2^{\circ}, 42.6^{\circ}, 44.7^{\circ}, 54.8^{\circ}\right.$, and $\left.77.6^{\circ}\right)$. The peaks attributed to crystalline $\mathrm{MnO}_{x}\left(\mathrm{MnO}_{2}\right.$, $\mathrm{Mn}_{3} \mathrm{O}_{4}, \mathrm{MnO}$ ) were observed and mainly assigned to $\mathrm{Mn}_{3} \mathrm{O}_{4}$. From Fig. 3(4), it was shown that $\mathrm{CeO}_{2}\left(2 \theta=28.5^{\circ}, 33.0^{\circ}, 47.5^{\circ}\right.$, and $56.3^{\circ}$ ) was the dominant phase for $\mathrm{CeO}_{x}$ in $\mathrm{Ce} / \mathrm{MWCNTs}$ catalyst. The peaks of graphite for this catalyst were noticeably lower than those for the Mn/MWCNTs catalyst. With the introduction of Ce to the Mn/MWCNTs catalysts, the peaks of $\mathrm{MnO}_{x}$ declined $(\mathrm{Ce} / \mathrm{Mn}=0.6)$ or even disappeared $(\mathrm{Ce} / \mathrm{Mn}=$ 1.8). Manganese oxide interacts with the cerium oxide in these catalysts. This reaction would disturb the $\mathrm{MnO}_{x}$ crystal struc-

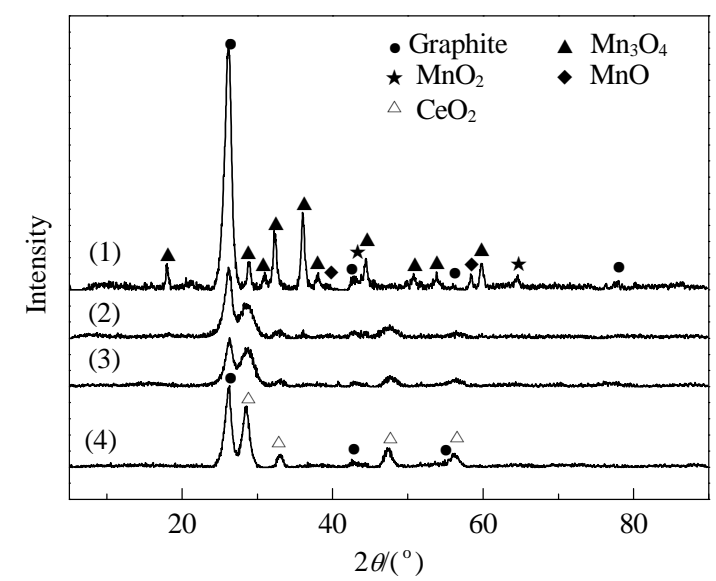

Fig. 3. XRD patterns of various catalysts. (1) Mn/MWCNTs; (2) Mn-Ce(0.6)/MWCNTs; (3) Mn-Ce(1.8)/MWCNTs; (4) Ce/MWCNTs. 
ture and diminish the volume of $\mathrm{MnO}_{x}$ crystal particles [33]. The tiny crystal particles uniformly disperse on the MWCNTs and enlarge the effective interface, improving the catalytic activity. By contrast, the typical peaks of $\mathrm{CeO}_{2}$ for the Mn-Ce/MWCNTs catalysts were clearly observed but were slightly broader than those of the Ce/MWCNTs catalyst. It indicates that their $\mathrm{CeO}_{2}$ crystallinity was lower than that of the Ce/MWCNTs. Ce modification also broadens the typical peaks of graphite. This is mainly because: (i) Ce modification disturbs the crystal structure and diminishes the volume of the crystal particles. The tiny crystal particles uniformly adsorb on the MWCNTs and weaken the detection of graphite in the XRD characterization, and (ii) A mass of metal oxide particles inside the MWCNTs disturb the structure of the graphite.

\subsection{4. $H_{2}$-TPR results}

Figure 4 shows the $\mathrm{H}_{2}$-TPR curves of various catalysts. The $\mathrm{Mn} / \mathrm{MWCNTs}$ catalysts present two redox peaks at $290^{\circ} \mathrm{C}$ and $410^{\circ} \mathrm{C}$, which correspond to the reduction of $\mathrm{MnO}_{2}$ or $\mathrm{Mn}_{2} \mathrm{O}_{3}$ to $\mathrm{Mn}_{3} \mathrm{O}_{4}$, and $\mathrm{Mn}_{3} \mathrm{O}_{4}$ to $\mathrm{MnO}$, respectively. A weak peak at $230^{\circ} \mathrm{C}$ is also attributed to the reduction of $\mathrm{MnO}_{2}$ to $\mathrm{Mn}_{3} \mathrm{O}_{4}$ [17,32]. The $\mathrm{H}_{2}$ consumption of the Mn/MWCNTs catalyst was 0.99 $\mathrm{mmol} / \mathrm{g}$. For catalysts with MWCNTs support, the hydrogen consumption peaks of $\mathrm{MnO}_{x}$ and $\mathrm{CeO}_{2}$ are located at lower temperatures than those for catalysts with no support [35] or with other supports, such as $\mathrm{TiO}_{2}$ [16,31], $\mathrm{Al}_{2} \mathrm{O}_{3}$ [36], zeolite $\mathrm{NaY}$ [37], or $\mathrm{TiO}_{2}$-pillared clays [6]. This indicated that MWCNTs would improve the oxidizability of the metal oxides.

In the case of Mn-Ce/MWCNTs catalysts, the $\mathrm{H}_{2}$ consumption peaks of $\mathrm{Mn}_{3} \mathrm{O}_{4}$ and $\mathrm{CeO}_{2}$ overlap each other. The $\mathrm{H}_{2}$-TPR patterns for the Mn-Ce/MWCNTs catalysts were similar to that of the Mn/MWCNTs catalyst, but with some apparent changes. First, the peaks are moved towards lower or higher temperatures. Compared with the reduction peak of $\mathrm{MnO}_{2}$ or $\mathrm{Mn}_{2} \mathrm{O}_{3}$ to $\mathrm{Mn}_{3} \mathrm{O}_{4}$ of $\mathrm{Mn} / \mathrm{MWCNTs}$ catalyst, the peak for Mn-Ce(0.6)/MWCNTs catalyst was shifted by $40{ }^{\circ} \mathrm{C}$ towards the lower temperature side. With increased Ce loading $(\mathrm{Ce} / \mathrm{Mn}=$ 1.8), this peak turns to move to a higher temperature side. This might be due to the crystalline $\mathrm{CeO}_{2}$ structure of Mn-Ce(1.8)/MWCNTs being more apparent than for Mn-Ce(0.6)/MWCNTs in the XRD results. For the Mn-Ce(1.8)/MWCNTs catalyst, excess $\mathrm{CeO}_{x}$ aggregated together and formed more crystalline $\mathrm{CeO}_{x}$, reducing mobility of the lattice oxygen. Naturally, the valence and oxidizability of manganese decreased. Considering the SCR activity, it was found that the movement of the reduction peak of $\mathrm{MnO}_{2}$ or $\mathrm{Mn}_{2} \mathrm{O}_{3}$ to $\mathrm{Mn}_{3} \mathrm{O}_{4}$ was in accordance with the SCR activity. Second, the addition of Ce to Mn/MWCNTs catalyst increased the consumption of $\mathrm{H}_{2}$. When the values of the Ce/Mn ratios were 0.6

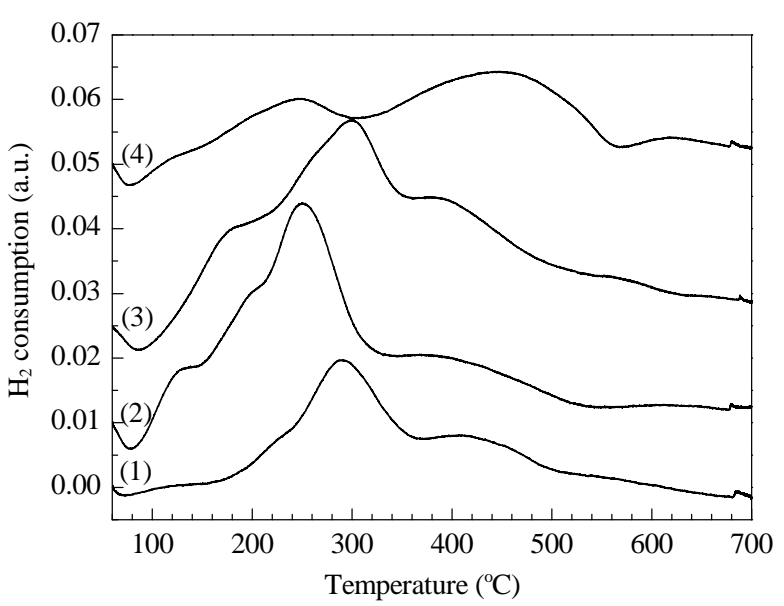

Fig. 4. $\mathrm{H}_{2}$-TPR profiles of various catalysts. (1) Mn/MWCNTs; (2) Mn-Ce(0.6)/MWCNTs; (3) Mn-Ce(1.8)/MWCNTs; (4) Ce/MWCNTs.

and 1.8, the $\mathrm{H}_{2}$ consumption was 1.52 and $1.87 \mathrm{mmol} / \mathrm{g}$, respectively. These values were much larger than those of the Mn/MWCNTs and Ce/MWCNTs catalysts. This indicates that Ce could improve the oxidizability and oxygen storage capacity of the catalysts. Jin et al. [18] have investigated the $\mathrm{NH}_{3}$-SCR reaction mechanism for catalysts of $\mathrm{Mn}$-Ce oxide supported on two supports $\left(\mathrm{TiO}_{2}\right.$ and $\left.\mathrm{Al}_{2} \mathrm{O}_{3}\right)$. They found that with catalyst support of $\mathrm{TiO}_{2}$, $\mathrm{NO}$ was oxidized to $\mathrm{NO}_{2}$ by lattice oxygen and then participated into the reaction. With $\mathrm{Al}_{2} \mathrm{O}_{3}$ as a catalyst support, $\mathrm{NO}$ was oxidized to $\mathrm{NO}_{2}$ by $\mathrm{O}_{2}$. It has been suggested that the improvement of oxidizability of Mn-Ce based catalysts would enhance SCR activity as well as the oxidation of NO. It should be specified that there was no apparent variation in the location of the $\mathrm{Mn}$ reduction peaks at higher temperatures $\left(\mathrm{Mn}_{3} \mathrm{O}_{4}\right.$ to $\mathrm{MnO}$ ) for all $\mathrm{Mn}$-based samples. It can be concluded that the active sites on $\mathrm{MnO}_{2}$ and $\mathrm{Mn}_{2} \mathrm{O}_{3}$ were dominant factors for SCR activity. By contrast, $\mathrm{Mn}_{3} \mathrm{O}_{4}$ and $\mathrm{MnO}$ appear to have little effect on SCR activity.

\subsubsection{XPS results}

To further investigate the effects of Ce on the chemical state and surface composition in the near-surface region of Mn/MWCNTs catalyst, XPS analysis was conducted. The atomic surface compositions are given in Table 2. After adding Ce to the Mn/MWCNTs catalyst, the amounts of surface carbon and manganese were varied. It was shown that the amount of surface carbon declined with addition of $\mathrm{Ce}$. This was due to the enhanced dispersion of the metal oxides. The covered areas of the MWCNTs were enlarged by the well-dispersed metal oxides. Meanwhile, the amount of surface manganese declined by more than $30 \%$. This has been attributed to two reasons: (i)

Table 2

Atomic surface compositions of the catalysts obtained with XPS.

\begin{tabular}{|c|c|c|c|c|c|c|c|c|c|c|}
\hline \multirow{2}{*}{ Sample } & \multicolumn{4}{|c|}{ Surface composition $(x \%)$} & \multirow{2}{*}{$\mathrm{MnO}_{2} / \mathrm{MnO}_{x}$} & \multirow{2}{*}{$\mathrm{Mn}_{2} \mathrm{O}_{3} / \mathrm{MnO}_{x}$} & \multirow{2}{*}{$\mathrm{Mn}_{3} \mathrm{O}_{4} / \mathrm{MnO}_{x}$} & \multirow{2}{*}{ 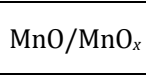 } & \multirow{2}{*}{$\mathrm{Ce}^{4+} / \mathrm{Ce}^{3+}$} & \multirow{2}{*}{$\mathrm{O}_{\text {lattice }} / \mathrm{O}_{\mathrm{ads}}$} \\
\hline & $\mathrm{C}$ & 0 & $\mathrm{Mn}$ & $\mathrm{Ce}$ & & & & & & \\
\hline Mn/MWCNTs & 92.77 & 4.95 & 2.28 & - & 0.51 & - & 0.48 & 0.01 & - & 0.68 \\
\hline Mn-Ce(0.6)/MWCNTs & 87.25 & 9.15 & 1.47 & 2.13 & 0.57 & - & 0.43 & - & 4.67 & 0.88 \\
\hline Mn-Ce(1.8)/MWCNTs & 84.92 & 9.86 & 1.53 & 3.69 & 0.52 & 0.48 & - & - & 6.37 & 1.46 \\
\hline Ce/MWCNTs & 89.81 & 9.70 & - & 0.49 & - & - & - & - & 11.32 & 0.10 \\
\hline
\end{tabular}



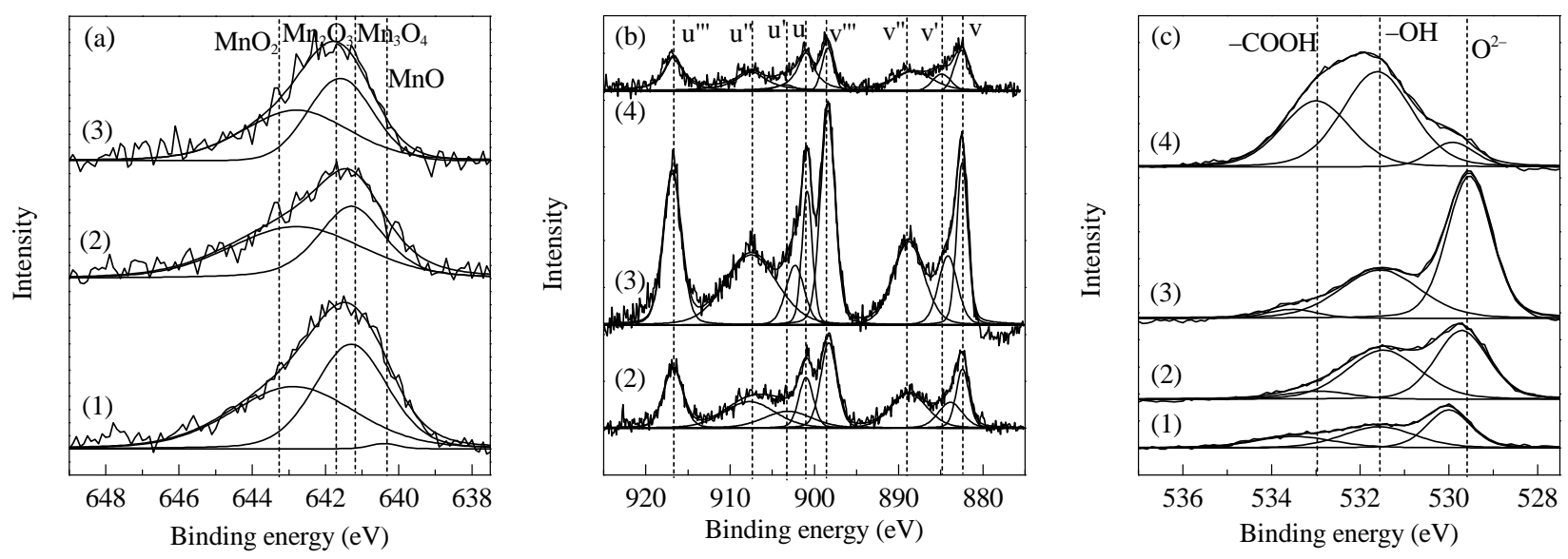

Fig. 5. XPS profiles of various catalysts. (a) Mn 2p p/2; (b) Ce 3d; (c) 0 1s. (1) Mn/MWCNTs; (2) Mn-Ce(0.6)/MWCNTs; (3) Mn-Ce(1.8)/MWCNTs; (4) Ce/MWCNTs.

The interaction between Mn and Ce causes some tiny metal oxides particles to form and are introduced into the inner MWCNTs, where some metal atoms were unable to be detected under the XPS measurement. (ii) The semi-diameters of $\mathrm{Mn}^{\mathrm{n}+}$ $\left(\mathrm{Mn}^{4+}, \mathrm{Mn}^{3+}\right.$, and $\mathrm{Mn}^{2+}$ are $0.053,0.058$, and $0.080 \mathrm{~nm}$, respectively) were lower than that of $\mathrm{Ce}^{4+}(0.094 \mathrm{~nm})$ in $\mathrm{CeO}_{2}$. This allows $\mathrm{Mn}^{\mathrm{n}}$ to enter into the $\mathrm{CeO}_{2}$ lattices but avoid being detected. In contrast, the surface Ce on the Mn-Ce/MWCNTs catalyst was greater than that of the Ce/MWCNTs. This is expected to be because of $\mathrm{CeO}_{x}$ particles on the $\mathrm{Ce} / \mathrm{MWCNTs}$ aggregating together, causing some $\mathrm{Ce}$ atoms to be hidden. For the Mn-Ce/MWCNTs catalyst, more Ce atoms were unfolded because of the tiny metal oxide particles. The detected ratio of surface Ce to $\mathrm{Mn}$ was larger than the mixed ratio of $\mathrm{Ce} / \mathrm{Mn}$ in the catalyst preparation. This was mainly because of the hidden $\mathrm{Mn}^{n+}$ ions in the $\mathrm{CeO}_{2}$ lattices $[31,32]$.

The characteristic peaks for Mn $2 p_{3 / 2}$, Ce $3 d$ and $01 s$ core level spectra are shown in Fig. 5. The peaks at 642.8, 641.3-641.4, 641.6-641.7, and 640.4 eV represent $\mathrm{MnO}_{2}$, $\mathrm{Mn}_{2} \mathrm{O}_{3}, \mathrm{Mn}_{3} \mathrm{O}_{4}$, and $\mathrm{MnO}$, respectively $[19,38] . \mathrm{MnO}_{2}$ was the predominant phase of $\mathrm{Mn}$ for all the samples. The ratio of $\mathrm{MnO}_{2}$ to $\mathrm{MnO}_{x}$ increased with the addition of $\mathrm{Ce}$, in accordance with the SCR activity. $\mathrm{CeO}_{2}$ would improve the oxygen storage capacity and the valence of manganese [15]. In the case of the valence of cerium (Fig. 5(b)), characteristic peaks u, u", u'", v, $v^{\prime \prime}$, and v"' attributed to $\mathrm{Ce}^{4+}$, and peaks $\mathrm{u}^{\prime}$ and v' corresponded to $\mathrm{Ce}^{3+}[6,33]$. It was shown that Ce mainly exists as $\mathrm{Ce}^{4+}$. The ratio of $\mathrm{Ce}^{4+}$ to $\mathrm{Ce}^{3+}$ is shown in Table 2 .

It was noted that surface oxygen on the Mn/MWCNTs catalysts was $4.95 \%$ and increased by $4 \%-5 \%$ with the addition of Ce. This is in agreement with the conclusion found in the $\mathrm{H}_{2}$-TPR study that Ce improves the oxygen storage capacity of the catalysts. From the XPS patterns of $01 s$ (Fig. (c)), it is shown that there were two kinds of surface oxygen for these catalysts, including lattice oxygen and chemisorption oxygen. The XPS results show that $-\mathrm{OH}$ and $-\mathrm{COOH}$ were the main species of chemisorption oxygen. For Mn/MWCNTs catalyst, the predominant species of oxygen was of surface chemisorption oxygen. With increased Ce loading, the amount of surface lat- tice oxygen exceeded the amount of surface chemisorption oxygen. Jin et al. [18] found that $\mathrm{NO}$ was oxidized to $\mathrm{NO}_{2}$ and then participated in the SCR reaction for $\mathrm{Mn}-\mathrm{Ce} / \mathrm{TiO}_{2}$ catalysts. Lattice oxygen could also oxidize $\mathrm{NH}_{3}$ to $\mathrm{NH}_{2}$, which then reacts with nitro-oxidized species $[33,39]$. It could be concluded that lattice oxygen of these catalysts could improve the SCR activity. The ratio of surface lattice oxygen to surface chemisorption oxygen was denoted as $\mathrm{O}_{\text {lattice }} / \mathrm{O}_{\text {ads }}$ in Table 2 . According to the SCR activity test results, it was found that the $\mathrm{NO}_{x}$ conversion was the highest with an $\mathrm{O}_{\text {lattice }} / \mathrm{O}_{\text {ads }}$ ratio of 4.67 . It was reported $[11,40]$ that oxygen was important for the SCR reaction of Mn-based catalysts. It improves the process of $\mathrm{NH}_{3}$ dehydrogenation (initiation of the SCR reaction) and the oxidization of NO to higher oxidation states. The SCR activity was subsequently improved. In conclusion, the amount of oxygen in the Mn-Ce/MWCNTs catalysts was found to dominate SCR activity.

\section{Conclusions}

Mn-Ce/MWCNTs catalysts had higher SCR activity than Mn/MWCNTs catalyst when prepared by a pore volume method. The addition of cerium enhances the dispersion of metal oxides on the surface of the MWCNTs and enlarges the specific surface area of the Mn/MWCNTs catalyst. Phase and structure are the dominant influencing factors on SCR activity for Mn-Ce/MWCNTs acting as catalysts. The addition of Ce increases the valence of $\mathrm{Mn}$ and forms $\mathrm{MnO}_{2}$ and $\mathrm{Mn}_{2} \mathrm{O}_{3}$, offering more active sites for reaction. Ce also improves the oxygen storage capacity and the amount of surface oxygen on the catalyst, and enhances the dehydrogenation of $\mathrm{NH}_{3}$ and the oxidization of NO. In addition, Ce reduces the crystallinity of the $\mathrm{Mn}$-Ce/MWCNTs catalysts. $\mathrm{MnO}_{x}$ mainly exists in an amorphous state or microcrystal structure for these catalysts.

\section{References}

[1] Tang X L, Hao J M, Xu W G, Li J H. Chin J Catal (唐晓龙, 郝吉明, 徐 文国, 李俊华. 催化学报), 2006, 27: 843

[2] Zamudio M A, Russo N, Fino D. Ind Eng Chem Res, 2011, 50: 6668 


\title{
Graphical Abstract
}

Chin. J. Catal., 2013, 34: 1087-1097 doi: 10.1016/S1872-2067(11)60520-2

\section{Effects of cerium on the selective catalytic reduction activity and structural properties of manganese oxides supported on} multi-walled carbon nanotubes catalysts

LI li, WANG Lishan, PAN Siwei, WEI Zhengle, HUANG Bichun*

Electric Power Research Institute of Guangdong Power Grid Corporation; South China University of Technology;

Guangzhou HKUST Fok Ying Tung Graduate School;

Guangdong Provincial Key Laboratory of Atmospheric Environment and Pollution Control
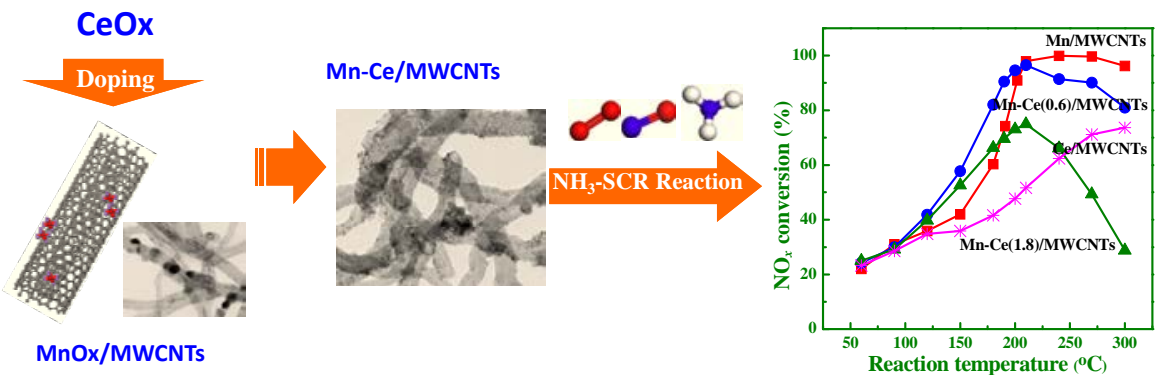

This study examines the effects of cerium on the selective catalytic reduction (SCR) activity and the structure of Mn/MWCNTs by comparing SCR activity, specific surface area, crystallization, oxidizability, and superficial species and elements.

[3] Liu F D, Shan W P, Shi X Y, Zhang C B, He H. Chin J Catal (刘福东, 单文坡, 石晓燕, 张长斌, 贺泓. 催化学报), 2011,32: 1113

[4] Liu F D, He H, Ding Y, Zhang C B. Appl Catal B, 2009, 93: 194

[5] Yao G-H, Gui K-T, Wang F. Chem Eng Technol, 2010, 33: 1093

[6] Shen B X, Yao Y, Ma H Q Liu T. Chin J Catal (沈伯雄, 姚燕, 马宏卿, 刘宁. 催化学报), 2011, 32: 1803

[7] Costa C N, Efstathiou A M. Appl Catal B, 2007, 72: 240

[8] Liu X Y, Jiang Z, Chen M X, Shi J W, Zhang Z X, Shangguan W F. Ind Eng Chem Res, 2011, 50: 7866

[9] Tang X L, Hao J M, Yi H H, Li J H. Catal Today, 2007, 126: 406

[10] Liu W, Tong Z Q, Luo J. Acta Sci Circumstant (刘炜, 童志权, 罗婕. 环境科学学报), 2006, 26: 1240

[11] Wu Z B, Jiang B Q, Liu Y, Wang H Q, Jin R B. Environ Sci Technol, 2007, 41: 5812

[12] Wu Z B, Jiang B Q, Liu Y, Zhao W R, Guan B H. J Hazard Mater, 2007, 145: 488

[13] Kang M, Park E D, Kim J M, Yie J E. Appl Catal A, 2007, 327: 261

[14] Qi G, Yang R T, Chang R. Appl Catal B, 2004, 51: 93

[15] Huang Y, Tong Z Q, Wu B, Zhang J F. J Fuel Chem Technol (黄妍, 童 志权, 伍斌, 张俊丰. 燃料化学学报), 2008, 36: 616

[16] Wu Z B, Jin R B, Liu Y, Wang H Q. Catal Commun, 2008, 9: 2217

[17] Fan X Y, Qiu F M, Yang H S, Tian W, Hou T F, Zhang X B. Catal Commun, 2011, 12: 1298

[18] Jin R B, Liu Y, Wu Z B, Wang H Q, Gu T T. Chemosphere, 2010, 78: 1160

[19] Lin Q, Li J, Ma L, Hao J. Catal Today, 2010, 151: 251

[20] Bao X H. Sci China, Ser B (包信和. 中国科学B辑), 2009, 39: 1125

[21] Lambin P, Fonseca A, Vigneron J P, Nagy J B, Lucas A A. Chem Phys Lett, 1995, 245: 85

[22] Long R Q, Yang R T. Ind Eng Chem Res, 2001, 40: 4288
[23] Ajayan P M. Chem Rev, 1999, 99: 1787

[24] Li Q, Yang H, Qiu F, Zhang X.J Hazard Mater, 2011, 192: 915

[25] Huang B, Huang R, Jin D, Ye D. Catal Today, 2007, 126: 279

[26] Luo Y, Li C T, Lu P, Li Q, Ke Q, Tian L H. Chin J Environ Eng (罗瑶, 李彩亭, 路培, 李群, 柯琪, 田立辉. 环境工程学报), 2009, 3: 1844

[27] Wang W H, Huang B C, Wang L S, Ye D Q. Surf Coat Technol, 2011, 205: 4896

[28] Zhou G, Zhong B, Wang W, Guan X, Huang B, Ye D, Wu H. Catal Today, 2011, 175: 157

[29] Grossale A, Nova I, Tronconi E. Catal Today, 2008, 136: 18

[30] Zhang Y P, Wang X L, Sun K Q, Shen K, Xu H T, Zhou C C. J Fuel Chem Technol (张亚平, 汪小蕾, 孙克勤, 沈凯, 徐海涛, 周长城. 燃料化学学报), 2011, 39: 782

[31] Gong L, Luo L T, Wang R, Ao Z Y, Zhang N. J Chin Rare Earth Soc (供 否, 罗来涛, 王瑞, 敖志勇, 张宁. 中国稀土学报), 2011, 29: 41

[32] Kijlstra W S, Brands D S, Poels E K, Bliek A. J Catal, 1997, 171: 208

[33] Wu X, Si Z, Li G, Weng D, Ma Z.J Rare Earths, 2011, 29: 64

[34] Huang Q, Xue X, Zhou R. J Hazard Mater, 2010, 183: 694

[35] Liu X, Lu J, Qian K, Huang W, Luo M. J Rare Earths, 2009, 27: 418

[36] Smirniotis P G, Sreekanth P M, Peña D A, Jenkins R G. Ind Eng Chem Res, 2006, 45: 6436

[37] Richter M, Trunschke A, Bentrup U, Brzezinka K-W, Schreier E, Schneider M, Pohl M-M, Fricke R. J Catal, 2002, 206: 98

[38] National Institute of Standards and Technology (NIST). X-ray Photoelectron Spectroscopy Database. Accessed on March 10, 2012, http://srdata.nist.gov/xps

[39] Kijlstra W S, Brands D S, Smit H I, Poels E K, Bliek A. J Catal, 1997, 171: 219

[40] Wu D W, Zhang Q L, Lin T, Gong M C, Chen Y Q. Chin J Inorg Chem (吴 大旺, 张秋林, 林涛, 龚茂初, 陈耀强. 无机化学学报), 2011,27:5

\section{Ce掺杂对碳纳米管负载Mn催化剂结构及 SCR反应性能的影响}

\author{
李 丽 ${ }^{\mathrm{a}}$, 王丽珊 ${ }^{\mathrm{b}, \mathrm{c}}$, 盘思伟 ${ }^{\mathrm{a}}$ ，韦正乐 ${ }^{\mathrm{a}, \mathrm{b}}$ ，黄碧纯 ${ }^{\mathrm{b}, \mathrm{d},{ }^{*}}$ \\ $\mathrm{a}$ 广东电网公司电力科学研究院, 广东广州 510080
}




\section{b华南理工大学环境科学与工程学院, 广东广州 510006 \\ c广州市香港科大霍英东研究院大气研究中心, 广东广州511458 \\ d广东省大气环境与污染控制重点实验室, 广东广州510006}

摘要: 采用等体积浸渍法制备多壁碳纳米管(MWCNTs)负载Ce-Mn的催化剂, 考察了Ce掺杂对 $\mathrm{Mn} / \mathrm{MWCNTs}$ 催化剂上 $\mathrm{NH}_{3}$ 选择性 催化还原 $(\mathrm{SCR}) \mathrm{NO}_{x}$ 反应活性的影响. 并运用透射电镜扫描、 $\mathrm{N}_{2}$ 吸附-脱附、程序升温还原、X射线光电子能谱、X射线衍射等手 段, 重点考察了Ce掺杂对Mn/MWCNTs催化剂结构性质的影响. 结果表明, Ce掺杂能显著提高催化剂的SCR活性, 其活性增量随着 Ce含量的增加先增大后减小; 当 Ce/Mn为 0.6 时, 催化剂活性最佳. 表征结果显示, Mn/MWCNTs中添加Ce后, 金属氧化物在 MWCNTs上的分散程度提高; 催化剂的比表面积和孔体积增大, 平均孔径减小; 氧化能力提高; 表面氧含量增加, Mn化合价升高; 结晶度降低, $\mathrm{Mn}$ 主要以无定形或微晶形式存在, $\mathrm{Ce}$ 主要以 $\mathrm{CeO}_{2}$ 物相存在.

关键词: 选择性催化还原; 氮氧化物; 铈; 锰; 多壁碳纳米管

收稿日期: 2012-11-05. 接受日期: 2012-12-21. 出版日期: 2013-06-20.

*通讯联系人. 电话: (020)39380516; 传真: (020)39380518; 电子信箱: cebhuang@scut.edu.cn

基金来源：国家自然科学基金(20977034).

本文的英文电子版由Elsevier出版社在ScienceDirect上出版(http://www.sciencedirect.com/science/journal/18722067).

\section{1. 前言}

选择性催化还原(SCR)是目前用于固定源氮氧化物 $\left(\mathrm{NO}_{x}\right)$ 排放控制的主要技术. SCR技术的核心是催化剂, 其性能直接影响到SCR系统的整体脱硝效果. 然而, 目前 常用的商业催化剂 $\mathrm{V}_{2} \mathrm{O}_{5}-\mathrm{WO}_{3}\left(\mathrm{MoO}_{3}\right) / \mathrm{TiO}_{2}$ 活性温度窗口 高 $\left(300 \sim 400{ }^{\circ} \mathrm{C}\right)$, 易受 $\mathrm{SO}_{2}$ 和粉尘的影响而发生催化剂中 毒 ${ }^{[1,2]}$. 开发低温SCR 催化剂, 让脱硝系统置于除尘脱硫 装置之后 $\left(<200^{\circ} \mathrm{C}\right)$ 是解决这些问题的重要途径.

近年来, 高效低温SCR催化剂的开发成为该领域的 研究热点. 目前有关不同活性组分和载体的低温 $(<200$ $\left.{ }^{\circ} \mathrm{C}\right) \mathrm{NH}_{3}$-SCR 脱硝催化剂的报道较多 ${ }^{[3]}$. Liu等 ${ }^{[4]}$ 制备的 $\mathrm{Fe}_{0.9} \mathrm{Mn}_{0.1} \mathrm{TiO}_{x}$ 催化剂因具有较大的比表面积、合适的结 构、较强的氧化性能、较高的晶格氧迁移能力而表现出 较高的低温催化活性, 在 $200^{\circ} \mathrm{C}$ 附近 $\mathrm{NO}_{x}$ 转化率达到 $90 \%$ 以上．Zamudio 等 ${ }^{[2]}$ 采用凝胶燃烧合成法制得的 $\mathrm{Mn}_{0.95} \mathrm{Ca}_{0.05} \mathrm{Cr}_{2} \mathrm{O}_{4}$ 催化剂在 $125^{\circ} \mathrm{C}$ 时即可达到最高的 $\mathrm{NO}$ 转化率. $\mathrm{Yao}$ 等 ${ }^{[5]}$ 研究 $\gamma-\mathrm{Fe}_{2} \mathrm{O}_{3}$ 催化剂时发现, $250{ }^{\circ} \mathrm{C}$ 时 $\mathrm{NO}_{x}$ 转化率即达到 $90 \%$ 以上, 这与 $\gamma-\mathrm{Fe}_{2} \mathrm{O}_{3}$ 的磁性有关. Shen 等 ${ }^{[6]}$ 采用浸渍法制备Mn/钛基层柱粘催化剂后, 考察 了 Ce的添加对该催化剂在SCR反应中抗水抗硫性能的 影响. 研究发现, 添加Ce后其活性以及抗硫能力均有所 提高, $200^{\circ} \mathrm{C}$ 时 $\mathrm{NO}$ 去除率达到 $95 \%$, 同时 $\mathrm{SO}_{2}$ 的存在使得 失活速率降低.

在众多用作低温SCR 催化剂活性组分的过渡金属 及其氧化物中 ${ }^{[2,5-8]}, \mathrm{Mn}, \mathrm{Ce}$ 及其氧化物因其自身独特的 化学性质而表现出良好的低温SCR活性. 鿭氧化物表面 具有较多不稳定晶格氧原子, 因而有较强的氧化还原能 $力^{[1,9 \sim 12]}$. Kang等 ${ }^{[13]}$ 采用沉淀法制备了非负载型 $\mathrm{MnO}_{x}$ 催
化剂, $100{ }^{\circ} \mathrm{C}$ 时 $\mathrm{NO}_{x}$ 转化率达到 $90 \%$ 以上. $\mathrm{CeO}_{2}$ 可通过 $\mathrm{Ce}^{4+}$ 和 $\mathrm{Ce}^{3+}$ 间的转化, 实现氧的释放和储存 ${ }^{[14]}$. 黄妍等 ${ }^{[15]}$ 和 $\mathrm{Wu}$ 等 $^{[16]}$ 的研究表明, Ce的掺杂可提高 SCR 催化剂的 低温催化活性.

$\mathrm{TiO}_{2}, \mathrm{Al}_{2} \mathrm{O}_{3}$, 分子篎和碳材料等广泛用作低温 $\mathrm{SCR}$ 催化剂载体 ${ }^{[9,17 \sim 19]}$. 其中, 碳材料具有大比表面积、特殊 孔道结构、强吸附性能, 因而其负载的催化剂表现出优 异的性能. 作为一种特殊的碳材料的碳纳米管, 具有机 械强度高、热稳定性高、限域效应, 以及良好的导电性 等 ${ }^{[20233]}$, 因而广泛用作催化剂载体 ${ }^{[2426]}$.

因此, 本文以MWCNTs 为载体, 采用等体积浸渍法 负载Ce-Mn双组分, 运用透射电子显微镜(TEM)、 $\mathrm{N}_{2}$ 吸附 一脱附、X射线光电子能谱 $(X P S) 、 X$ 射线衍射 $(X R D) 、 H_{2}$ 程序升温还原 $\left(\mathrm{H}_{2}-\mathrm{TPR}\right)$, 以及 $\mathrm{SCR}$ 反应活性测试, 探讨 $\mathrm{Ce}$ 的掺杂对 Mn/MWCNTs催化剂结构及其SCR反应活性的 影响.

\section{2. 实验部分}

\section{1. 催化剂的制备}

将碳纳米管(深圳市纳米港有限公司, 管径为 60 100 $\mathrm{nm}$ ) 置于 $100{ }^{\circ} \mathrm{C}$ 的硝酸水溶液 $(3 \mathrm{~mol} / \mathrm{L})$ 中水浴 $4 \mathrm{~h}$ 后, 用 去离子水洗涤至中性, 经 $80^{\circ} \mathrm{C}$ 烘干, 研磨后, 于 $\mathrm{O}_{2}$ 中用等 离子体 $(15 \mathrm{~W})$ 放电 $40 \mathrm{~min}$. 碳纳米管的 $\mathrm{HNO}_{3}$ 纯化和氧等 离子体预处理, 目的是在碳纳米管表面接枝含氧官能团, 提高其在水中的分散性,使催化剂制备过程中活性组分 的负载能在水相中进行 $[27]$.

采用等体积浸渍法制备系列Mn-Ce/MWCNTs催化 剂. 按照一定 $\mathrm{Ce} / \mathrm{Mn}$ 摩尔比配制乙酸锰和硝酸铈的各种 溶液, 分别加入经预处理的MWCNTs超声分散 $1 \mathrm{~h}$, 室温 
浸渍5 h. 混合物于 $100^{\circ} \mathrm{C}$ 干燥后, 在管式炉中空气气氛下 于 $400^{\circ} \mathrm{C}$ 焙烧 $2 \mathrm{~h}$. 所得催化剂记为 $\mathrm{Mn}-\mathrm{Ce}(x) / \mathrm{MWCNTs}$, 其中 $x$ 为Ce/Mn摩尔比. 同法制得Ce/MWCNTs催化剂, 其 中Ce含量同Mn-Ce(0.6)/MWCNTs. 上述所有样品中 Mn 的质量分数为 $10 \%$.

\section{2. 催化剂的活性评价}

催化剂的活性评价在石英玻璃连续流动固定床反 应器 (内径 $d=12 \mathrm{~mm}$ )中进行, 催化剂用量 $180 \mathrm{mg}$. 各种 反应气体的流量由质量流量计控制, 其中 $0.1 \% \mathrm{NH}_{3}$, $0.1 \% \mathrm{NO}, 5 \% \mathrm{O}_{2}, \mathrm{Ar}$ 为平衡气, 气体空速 $40000 \mathrm{~h}^{-1}$. 尾气 中 $\mathrm{NO}_{x}$ 浓度由美国Thermo Scientific公司的42i-HL型 $\mathrm{NO}_{x}$ 烟气分析仪测得, $\mathrm{N}_{2}$ 由气相色谱仪(GC9560型)测得. 在 稳定状态下, $\mathrm{NO}_{x}$ 转化率 $X\left(\mathrm{NO}_{x}\right)=\left(C_{\mathrm{NO} x}^{\mathrm{in}}-C_{\mathrm{NO} x}^{\mathrm{out}}\right) / C_{\mathrm{NO} x}^{\mathrm{in}}$

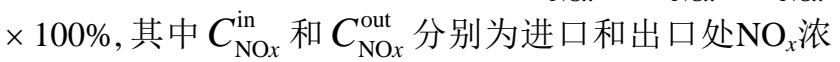
度.

\section{3. 催化剂的表征}

采用日本JEOL 公司的JEM-2100HR型TEM观察催 化剂微观形貌, 点分辨率 $0.23 \mathrm{~nm}$, 放大倍数 50 1500000, 加速电压100 200 kV.

采用美国Micromeritics公司的ASAP 2020 M型全自 动比表面积及微孔孔隙分析仪测定催化剂的比表面积 和孔结构参数. 样品用量 $0.1 \mathrm{~g}$, 样品先在 $100{ }^{\circ} \mathrm{C}$ 脱气 $1 \mathrm{~h}$, $350{ }^{\circ} \mathrm{C}$ 脱气 $4 \mathrm{~h}$, 然后以 $\mathrm{N}_{2}$ 为吸附质, 于 $-196{ }^{\circ} \mathrm{C}$ 下进行 $\mathrm{N}_{2}$ 吸附-脱附实验.

$\mathrm{H}_{2}$-TPR实验在美国Micromeritics公司的Auto Chem II 型全自动化学吸附仪中进行, 样品用量 $0.1 \mathrm{~g}$, 气体流速 $30 \mathrm{ml} / \mathrm{min}$, 在 $\mathrm{Ar}$ 吹扫下, 以 $10^{\circ} \mathrm{C} / \mathrm{min}$ 升至 $350{ }^{\circ} \mathrm{C}$ 并吹扫 1 h, 降至 $60{ }^{\circ} \mathrm{C}$, 通入 $10 \% \mathrm{H}_{2}-90 \% \mathrm{Ar}$ 混合气, 以 $10^{\circ} \mathrm{C} / \mathrm{min}$ 升 至 $700{ }^{\circ} \mathrm{C}, \mathrm{TCD}$ 记录耗 $\mathrm{H}_{2}$ 量.

XPS分析在英国Kratos公司的Axis Ultra DLD型X射 线光电子能谱仪上进行. 真空度为 $25 \times 10^{-4} \mathrm{~Pa}, \mathrm{Al} K_{\alpha}$ 射 线 $(h v=1486.6 \mathrm{eV}), \mathrm{C} 1 s$ 校准结合能为 $284.6 \mathrm{eV}$.

XRD分析在德国Bruker公司的D8 Advance型X射线 衍射仪上进行, $\mathrm{Cu} K_{a}$ 射线 $(\lambda=0.15418 \mathrm{~nm})$, 电压 $40 \mathrm{kV}$, 电流 $40 \mathrm{~mA}$, 扫描范围 $2 \theta=5^{\circ} \sim 90^{\circ}\left(\right.$ 步长 $\left.0.02^{\circ}\right)$. XRD结果 通过与JCPDS卡片对照进行分析.

\section{3. 结果与讨论}

\section{1. 催化剂的SCR活性}

图1为各催化剂上SCR反应活性. 由图可见, 当反应 温度低于 $120{ }^{\circ} \mathrm{C}$ 时, 各催化剂活性比较接近, 且在 20\% 40\%范围; 随着温度的上升, 各催化剂活性逐渐出
现显著的差异; 当高于 $240{ }^{\circ} \mathrm{C}$ 时, 各催化剂活性均普遍下 降. 高温时, 催化剂活性下降是因为发生了SCR的竞争反 应, $\mathrm{NH}_{3}$ 直接被 $\mathrm{O}_{2}$ 氧化 ${ }^{[28-30]}$.

对于 $\mathrm{Mn} / \mathrm{MWCNTs}$ 催化剂, 当反应温度低于 $180^{\circ} \mathrm{C}$ 时, $\mathrm{NO}_{x}$ 转化率低于 $60 \%$; 当升至 $210{ }^{\circ} \mathrm{C}$ 时, 迅速升至 97.9\%. 可见, 该催化剂的活化温度区间为 $180 \sim 210^{\circ} \mathrm{C}$. 当 温度为 $200 \sim 300{ }^{\circ} \mathrm{C}$ 时, $\mathrm{NO}_{x}$ 转化率保持在 $90 \%$ 以上, 活性 温度窗口较宽. Ce/MWCNTs 催化剂的 SCR 活性在 60 300 ${ }^{\circ} \mathrm{C}$ 区间内随着温度的上升而增加, 但表现出较低 的活性: $300{ }^{\circ} \mathrm{C}$ 时 $\mathrm{NO}_{x}$ 转化率仅为 $73.6 \%$. 另外, Ce的添加 使得 Mn/MWCNTs催化剂的高活性温度区间向低温偏 移; 随着催化剂中 Ce/Mn由 0.2 升至 1.8 , 催化剂活性及活 性温度窗口范围均是先增后减; $\mathrm{Ce} / \mathrm{Mn}$ 为 0.6 时, 催化剂 活性最佳, 活性温度窗口也最宽: 在190 $270{ }^{\circ} \mathrm{C} 反$ 应温度 区间内, $\mathrm{NO}_{x}$ 转化率保持在 $90 \%$ 以上.

为了探讨 Ce 掺杂对 Mn/MWCNTs催化剂脱硝性能 改善的原因及其对 $\mathrm{Mn}$ 在碳纳米管上的分散行为的影响, 下文选择Mn/MWCNTs, Ce/MWCNTs, 以及SCR活性较 为典型的 Mn-Ce(0.6)/MWCNTs与 $M n-C e(1.8) / M W C N T s$ 催化剂,对其作了系列的表征.

\section{2. 催化剂表征结果}

\subsubsection{TEM}

图 2 为不同催化剂的 TEM照片. 由图可见, 在 $\mathrm{Mn} / \mathrm{MWCNTs}$ 样品中 $\mathrm{MnO}_{x}$ 颗粒均匀附着在MWCNTs管 壁上, 粒径约为 $20 \sim 40 \mathrm{~nm}$; 而 $\mathrm{CeO}_{x}$ 在MWCNTs上的分散 性较差, 且团聚成大的颗粒物 (50 100 nm) 附着在 MWCNTs管壁上. 当Ce和Mn同时负载在MWCNTs上时, 金属氧化物在MWCNTs上的分散显著改善, 氧化物颗粒 的粒径降低到 $10 \mathrm{~nm}$ 以下, 有利于反应气体与金属氧化 物上的催化活性位充分接触, 从而提高催化剂的活性. 若Ce的添加量超过其在MWCNTs上的分散容量, 就会出 现金属氧化物的团聚, 使得催化活性位重叠相互掩盖而 降低催化活性. 还可以看出, 这种金属氧化物团聚物是 以疏松的絮状颗粒团形式存在的, 而并非像单一金属负 载时所观察到的较紧密的颗粒团.

\subsection{2. $\mathrm{N}_{2}$ 吸附-脱附}

表1列出了MWCNTs及其负载的催化剂的比表面 积、孔体积和孔径. 由表可见, 除Ce/MWCNTs样品外, 金 属氧化物的负载使得MWCNTs比表面积增加, 总孔体积 和平均孔径减小; 而单独负载Ce使MWCNTs比表面积 和总孔体积减小, 平均孔径则增加, 这主要是 $\mathrm{CeO}_{x}$ 在碳 管外堆积形成较致密的大颗粒所致. 比较而言, 单金属 
负载时, 催化剂的比表面积和孔体积均较小, 而平均孔径 较大. 当 Mn/MWCNTs催化剂中掺杂 Ce $(\mathrm{Ce} / \mathrm{Mn}=0.6)$ 后, 其比表面积和总孔体积分别增加了 $24 \%$ 和 $18 \%$, 平均孔 径则有所减小. 这是因为Ce掺杂后, Ce和 Mn的相互作用, 金属氧化物颗粒以无定形或微晶细小颗粒的形式高度 分散在碳纳米管上, 并形成许多细小的孔道, 金属颗粒物 充分裸露在外从而增加了催化剂的比表面积. 随着Ce掺 杂量的增加 $(\mathrm{Ce} / \mathrm{Mn}=1.8), A_{\mathrm{BET} T}$ 增加了近一倍, 总孔体积 继续增加, 这是因为 $\mathrm{Ce}$ 和 $\mathrm{Mn}$ 的氧化物除了负载在 MWCNTs上, 其中大于碳纳米管分散容量的部分形成了 疏松的絮状颗粒团. 然而, 当 $\mathrm{Ce} / \mathrm{Mn}$ 为 1.8 时, 催化剂的平 均孔径大幅度降低, 与龚磊等 ${ }^{[31]}$ 和 $\mathrm{Qi}$ 等 $^{[14]}$ 报道的非负载 型 $\mathrm{MnO}_{x}-\mathrm{CeO}_{2}$ 催化剂( $\mathrm{Ce} / \mathrm{Mn}$ 分别为2.3和2.5)的比较接 近. 结合催化剂的活性可知, 当 $\mathrm{Ce} / \mathrm{Mn}=0.6$ 时, 所制催化 剂大的比表面积和合适的孔道结构使其活性增加, 但催 化剂的比表面积与其活性并非呈线性关系: 当 Ce/Mn为 1.8 时, 虽然样品有更大的比表面积, 但其催化活性却反 而下降.

唐晓龙等 ${ }^{[1]}$ 研究指出, Mn基催化剂的活性主要取决 于其比表面积和物相结构. 较大的比表面积有利于反应 物在催化剂的表面吸附, 为催化反应提供更多的反应空 间, 从而提高 $\mathrm{NO}_{x}$ 的转化率 ${ }^{[10]}$. 低温时, 反应气体容易吸 附于催化剂上, 有利于反应进行. 如表1所示, 各催化剂的 比表面积相差较大, 而较低温度 $\left(<120^{\circ} \mathrm{C}\right)$ 时活性相当. 由此可见, 对于该Mn-Ce/MWCNTs系列催化剂, 在较低 的温度下,其单位表面积的金属氧化物活性位数量相差 较大. 随着温度的上升, 各催化剂的SCR活性没有因为反 应气体在高温下脱附而降低, 反而提高. 由此推测, 在较 高反应温度下, 该催化剂活性受其比表面积的影响减弱, 而更多地取决于催化剂上金属氧化物的物相结构(晶 相、价态等).

\subsubsection{XRD}

图3为各催化剂的XRD谱. 由图可见, Mn/MWCNTs 样品出现尖锐的石墨特征峰 $\left(2 \theta=26.2^{\circ}, 42.6^{\circ}, 44.7^{\circ}\right.$, $54.8^{\circ}$ 和 $\left.77.6^{\circ}\right)$, 并可看到多种 $\mathrm{MnO}_{x}$ 物相 $\left(\mathrm{MnO}_{2}, \mathrm{Mn}_{3} \mathrm{O}_{4}\right.$, $\mathrm{MnO}$ ), 其中以 $\mathrm{Mn}_{3} \mathrm{O}_{4}$ 物相为主; 而在Ce/MWCNTs催化剂 上, $\mathrm{CeO}_{2}$ 是 $\mathrm{CeO}_{x}$ 的主要存在物相 $\left(2 \theta=28.5^{\circ}, 33.0^{\circ}, 47.5^{\circ}\right.$ 和 $56.3^{\circ}$ ), 其石墨的特征峰明显较 Mn/MWCNTs催化剂的 宽化. 当Ce掺杂 $\mathrm{Mn}(\mathrm{Ce} / \mathrm{Mn}$ 为0.6)负载在 MWCNTs上时, $\mathrm{MnO}_{x}$ 各物相的特征峰减弱, 当 $\mathrm{Ce} / \mathrm{Mn}$ 为 1.8 时甚至消失. $\mathrm{Ce}$ 与 $\mathrm{Mn}$ 相互作用, 使 $\mathrm{MnO}_{x}$ 的晶体结构由有序向无序转 变, 混乱度提高, 阻碍了 $\mathrm{MnO}_{x}$ 的聚集和结晶, 使其晶粒变
小 ${ }^{[32]}$. 细小晶粒高度分散于载体上, 使催化剂有效界面 增大, 有利于其活性的提高. 相比之下, $\mathrm{CeO}_{2}$ 物相的特征 峰仍可明显分辨, 峰位置不变, 但出现了宽化, 可见 $\mathrm{CeO}_{2}$ 的结晶度也较单一负载时低. 此外, 当Ce掺杂后, 催化剂 的石墨特征峰较单独负载Mn或Ce时宽化. 这可能有两 种原因: (1)Ce掺杂使金属氧化物颗粒变得细小, 大量微 小金属颗粒高度附着在MWCNTs的外部, 阻碍XRD测试 时石墨层的探测; (2)许多颗粒进入到内管壁间, 使得 MWCNTs中的石墨片层结构受到扰乱.

\subsection{4. $\mathrm{H}_{2}$-TPR}

图4为各催化剂的 $\mathrm{H}_{2}$-TPR谱. Mn/MWCNTs催化剂 在 290 和 $410^{\circ} \mathrm{C}$ 附近出现了两个还原峰, 分别归属于 $\mathrm{Mn}$ 物种的分步还原 $\mathrm{MnO}_{2} / \mathrm{Mn}_{2} \mathrm{O}_{3} \rightarrow \mathrm{Mn}_{3} \mathrm{O}_{4} \rightarrow \mathrm{MnO}$; 另外, 在 $230{ }^{\circ} \mathrm{C}$ 处有一个微弱的肩峰, 可归属于 $\mathrm{MnO}_{2}$ 还原为 $\mathrm{Mn}_{2} \mathrm{O}_{3}{ }^{[17,33]}$; 该催化剂 $\mathrm{H}_{2}$ 耗量为 $0.75 \mathrm{mmol} / \mathrm{g}$. $\mathrm{Ce} / \mathrm{MWCNTs}$ 催化剂主要有两个还原峰 $\left(250\right.$ 和 $\left.450{ }^{\circ} \mathrm{C}\right)$, 分别归属于表面氧和晶格氧的还原 $\left(\mathrm{CeO}_{2}\right.$ 还原为 $\left.\mathrm{Ce}_{2} \mathrm{O}_{3}\right)^{[6,34]}$, 其 $\mathrm{H}_{2}$ 耗量为 $0.99 \mathrm{mmol} / \mathrm{g}$. 值得注意的是, MWCNTs负载的 $\mathrm{MnO}_{x}$ 和 $\mathrm{CeO}_{2}$ 的还原峰温度比一些非负 载型 ${ }^{[35]}$ 和其它材料负载 ${ }^{[6,16,31,36,37]}$ 的Ce基催化剂的低. 由 此可知, 以MWCNTs为载体时更有利于催化剂的还原, 从而提高了金属氧化物的氧化性能.

当 $\mathrm{Mn} / \mathrm{MWCNTs}$ 催化剂中掺入 $\mathrm{Ce}$ 时, $\mathrm{Mn}_{3} \mathrm{O}_{4}$ 和 $\mathrm{CeO}_{2}$ 的还原峰在350 500 ${ }^{\circ} \mathrm{C}$ 区间内发生重叠. 其还原峰整体 形状与 Mn/MWCNTs的大致相同, 但还原峰位置发生偏 移，如 Mn-Ce(0.6)/MWCNTs 催化剂的 $\mathrm{MnO}_{2} / \mathrm{Mn}_{2} \mathrm{O}_{3}$ $\rightarrow \mathrm{Mn}_{3} \mathrm{O}_{4}$ 还原峰向低温偏移了约 $40{ }^{\circ} \mathrm{C}$; 随着 $\mathrm{Ce}$ 含量的提 高, 该还原峰却向高温移动, 可能与 $\mathrm{Mn}-\mathrm{Ce}(1.8) /$ MWCNTs催化剂中 $\mathrm{CeO}_{2}$ 的XRD衍射峰明显有关, 即过 量 $\mathrm{CeO}_{x}$ 在发生聚集的过程中形成了较多的 $\mathrm{CeO}_{2}$ 结晶物 相, 一定程度上减弱了晶格氧的流动性, 导致Mn化学价 降低和氧化性能减弱. 结合活性评价结果发现, $\mathrm{MnO}_{2}$ 或 $\mathrm{Mn}_{2} \mathrm{O}_{3}$ 转化为 $\mathrm{Mn}_{3} \mathrm{O}_{4}$ 的还原峰偏移情况与催化剂活性一 致. 另外, $\mathrm{Ce}$ 的掺杂使得催化剂还原峰面积增大, 当 $\mathrm{Ce} / \mathrm{Mn}$ 为 0.6 和 1.8 时, $\mathrm{H}_{2}$ 消耗量分别是 1.52 和 $1.87 \mathrm{mmol} / \mathrm{g}$, 比单负载时的大得多. 这说明适量Ce的添加可提高催化 剂的氧化性能和储氧能力. Jin等 ${ }^{[18]}$ 研究了 $\mathrm{Mn}-\mathrm{Ce}$ 氧化物 分别负载在 $\mathrm{TiO}_{2}$ 和 $\mathrm{Al}_{2} \mathrm{O}_{3}$ 上的 $\mathrm{NH}_{3}-\mathrm{SCR}$ 反应机理发现, 催 化剂表面上 $\mathrm{NO}$ 均以其更高价的氧化物参与反应. 当 $\mathrm{TiO}_{2}$ 为载体时, $\mathrm{NO}$ 被表面晶格氧氧化为 $\mathrm{NO}_{2}$ 物种参与反 应; $\mathrm{Al}_{2} \mathrm{O}_{3}$ 为载体时, $\mathrm{NO}$ 被 $\mathrm{O}_{2}$ 氧化为 $\mathrm{NO}_{2}$ 后吸附于催化剂 上参与反应. 由此推测, 以 $\mathrm{Mn}-\mathrm{Ce}$ 氧化物为活性组分的催 
化剂的氧化性能的增强有利于 $\mathrm{NO}$ 在催化剂表面的氧化, 使得催化剂SCR活性增加. 需要指出的是, 各含Mn催化 剂中高温还原峰 $\left(\mathrm{Mn}_{3} \mathrm{O}_{4} \rightarrow \mathrm{MnO}\right)$ 的位置没有明显差异. 综上可见, $\mathrm{MnO}_{2}$ 和 $\mathrm{Mn}_{2} \mathrm{O}_{3}$ 上的活性位是影响该系列催化 剂SCR反应的主要因素, 而 $\mathrm{Mn}_{3} \mathrm{O}_{4}$ 和 $\mathrm{MnO}$ 的影响不大.

\subsubsection{XPS}

为了进一步研究Ce掺杂对 Mn/MWCNTs催化剂表 面氧含量的影响, 以及催化剂表面各元素含量和价态分 布, 对各催化剂进行了XPS表征. 所得催化剂表面各元素 含量列于表2. 可以看出, 催化剂表面碳含量随着Ce的掺 入而下降, 是因为Ce促进了金属氧化物在MWCNTs表面 的均匀分散, 增大了碳管外表面被金属氧化物覆盖的面 积. Ce掺杂后表面 Mn含量下降30\%以上,这可能有两方 面的原因: (1)Ce 与 $\mathrm{Mn}$ 的相互作用下形成颗粒细小的金 属氧化物, 可能进入到碳纳米管内部, 不能被XPS探测 到; (2) 离子半径较小的 $\mathrm{Mn}^{n^{+}}\left(\mathrm{Mn}^{4+}\right.$ (0.053 nm), $\mathrm{Mn}^{3+}$ $\left.(0.058 \mathrm{~nm}), \mathrm{Mn}^{2+}(0.080 \mathrm{~nm})\right)$ 进入到离子半径较大 $(0.094$ $\mathrm{nm})$ 的 $\mathrm{CeO}_{x}$ 晶格中, 导致 $\mathrm{Mn}$ 没能探测出来. 与此相反, Mn-Ce/MWCNTs催化剂表面Ce含量较单金属负载时高, 这是因为在 $\mathrm{Ce} / \mathrm{MWCNTs}$ 中 $\mathrm{CeO}_{x}$ 主要以大颗粒团聚物形 式存在, 导致大部分 $\mathrm{Ce}$ 包裹在大颗粒中, 使得表面Ce含 量偏低; 而当 $\mathrm{Ce}$ 与 $\mathrm{Mn}$ 作用后, 形成了细小的颗粒, 内部的 Ce向催化剂表面迁移. 另外, 在两种Mn-Ce/MWCNTs催 化剂中, 表面 $\mathrm{Ce} / \mathrm{Mn}$ 值均大于设定值, 这可能是因为在催 化剂制备过程中, 离子半径较小的 $\mathrm{Mn}^{n+}$ 进入到离子半径 较大的 $\mathrm{CeO}_{x}$ 晶格中, 导致表面的 $\mathrm{Mn} / \mathrm{Ce}$ 值比设定值 低 ${ }^{[31,33]}$.

XPS谱图拟合结果见图5. Mn $2 p_{3 / 2}$ 的电子结合能谱 峰中 $\mathrm{MnO}_{2}, \mathrm{Mn}_{2} \mathrm{O}_{3}, \mathrm{Mn}_{3} \mathrm{O}_{4}$ 和 $\mathrm{MnO}$ 的结合能分别是642.8, 641.3 641.4, 641.6 641.7和640.4 $\mathrm{eV}^{[19,38]}$. 由图5(a)可见, 各样品中 $\mathrm{Mn}$ 主要是以 $\mathrm{MnO}_{2}$ 形式存在, $\mathrm{MnO}_{2} / \mathrm{MnO}_{x}$ 值随 着Ce掺入及其含量的增加而增大, 并与催化剂活性变化 一致. $\mathrm{CeO}_{2}$ 提高了催化剂中氧的储存和转移能力, 促进 Mn由低价态氧化为高价态 ${ }^{[15]}$. Ce $3 d$ 轨道的XPS谱如图 5(b) 所示, 其中 u, u", u'"和 v, v", v"'峰归属于 $\mathrm{Ce}^{4+}$, 而 $\mathrm{u}^{\prime}$ 和 $v^{\prime}$
两个峰归属于 $\mathrm{Ce}^{3+[6,32]}$. 可见, $\mathrm{Ce}$ 主要以 $\mathrm{Ce}^{4+}$ 的形式存在 (各样品中 $\mathrm{Ce}^{4+} / \mathrm{Ce}^{3+}$ 的比见表2).

由表2可见, Mn/MWCNTs催化剂中氧含量为4.95\%, $\mathrm{Ce}$ 的掺入使得催化剂中氧含量增加了 $4 \% \sim 5 \%$, 即Ce使催 化剂的储氧能力提高, 这与 $\mathrm{H}_{2}-\mathrm{TPR}$ 结果一致. 由图5(c)可 知, 催化剂中氧原子包括了表面晶格氧和表面化学吸附 氧; 分峰拟合结果显示, 该系列催化剂的表面化学吸附 氧主要以 $-\mathrm{OH}$ 和-COOH两种形式存在. 表面晶格氧与表 面化学吸附氧的比值记为 $\mathrm{O}_{\text {lattice }} / \mathrm{O}_{\text {ads. }}$. MWCNTs单独负 载 $\mathrm{Mn}$ 时, 催化剂中的氧主要以表面化学吸附氧为主; 随 着掺入Ce量增多, Mn-Ce $(x) / M W C N T s$ 催化剂表面晶格 氧含量超过了表面吸附氧。Jin 等 ${ }^{[18]}$ 研究发现, $\mathrm{Mn}-\mathrm{Ce} / \mathrm{TiO}_{2}$ 催化剂上SCR反应过程是 $\mathrm{NO}$ 被表面晶格氧 氧化为 $\mathrm{NO}_{2}$ 物种参与反应. 另外, 晶格氧亦可将 $\mathrm{NH}_{3}$ 氧化 为 $\mathrm{NH}_{2}$, 并与 $\mathrm{NO}$ 氧化后的物种反应生成中间物种 ${ }^{[32,39]}$. 可见, 该系列催化剂晶格氧含量的增加有利于SCR反应 的进行. 结合活性评价结果可知, 当 $\mathrm{O}_{\text {lattice }} / \mathrm{O}_{\text {ads }}$ 为4.67时, Mn-Ce/MWCMTs催化剂的SCR活性最佳. 在Mn基催化 剂中, 氧对催化剂的活性起着重要的作用, 它可促进SCR 反应过程中 $\mathrm{NH}_{3}$ 的脱氢氧化( $\mathrm{SCR}$ 反应的起始步骤) 和 $\mathrm{NO}$ 氧化为反应中间物种硝酸根或者亚硝酸根等, 从而提高 催化剂的SCR活性 ${ }^{[11,40]}$. 可见, 催化剂氧含量的增加对于 催化剂的SCR活性提高起着本质的作用.

\section{4. 结论}

采用等体积浸渍法制备的Mn-Ce/MWCNTs催化剂 上SCR反应活性高于 Mn/MWCNTs催化剂. Ce的掺杂促 进了金属氧化物在载体MWCNTs上的分散, 增加了催化 剂的比表面积. Mn-Ce/MWCNTs催化剂的物相结构是 影响其SCR活性的主要因素. Ce提高了 Mn的价态, 形成 更多 $\mathrm{MnO}_{2}$ 和 $\mathrm{Mn}_{2} \mathrm{O}_{3}$, 为 SCR 反应提供更多活性位; 同时 提高了催化剂的储氧能力, 增加了催化剂的表面氧含量, 促进了 SCR反应过程中 $\mathrm{NH}_{3}$ 的脱氢氧化和 $\mathrm{NO}$ 的氧化. 另 外, Ce降低了催化剂的结晶度, 使 $\mathrm{MnO}_{x}$ 主要以无定形或 微晶形式存在. 